\title{
Analysis of the Chemical Bath and its Effect on the Physical Properties of CdS/ITO thin Films
}

\author{
S. Herrera, C. M. Ramos, R. Patiño, J. L. Peña, W. Cauich, and A. I. Oliva \\ Centro de Investigación y de Estudios Avanzados del IPN Unidad Mérida, \\ Departamento de Física Aplicada. AP. 73-Cordemex, 97310 Mérida Yucatán, Mexico
}

Received on 5 December, 2005

\begin{abstract}
Cadmium sulphide (CdS) thin films deposited on indium tin oxide (ITO) substrates were prepared by the chemical bath deposition technique at different values of $\mathrm{pH}$ and $\mathrm{pNH}_{3}$. This was made in order to analyze the influence of the initial chemical composition of the bath on some physical properties of the final CdS films, used as optical windows for solar cells. The mechanism proposed in the literature for this deposition involves the tetra-ammonium cadmium (II) complex, $\mathrm{Cd}\left(\mathrm{NH}_{3}\right)_{4}^{2+}$, at the start of the reaction. Following this mechanism, the change in the concentration of $\mathrm{Cd}\left(\mathrm{NH}_{3}\right)_{4}^{2+}$ gives a variation in the rate of deposition with the corresponding modification in the quality of the film. Therefore, the predominance zone diagram of $\mathrm{Cd}^{2+}$ species in solution as a function of the values of $\mathrm{pH}$ and $\mathrm{pNH}_{3}$ was used to analyze the reasons why the CdS/ITO thin films are favored in just a narrow range of ammonium and hydroxide concentrations. To obtain useful films, the results showed that low ammonium concentrations must be avoided at high $\mathrm{pH}$ values as well as high ammonium concentrations at lower $\mathrm{pH}$ values.
\end{abstract}

Keywords: Chemical bath analysis; Cadmium sulphide; Semiconductor film; Predominance diagrams

\section{INTRODUCTION}

Cadmium sulfide (CdS) is an excellent material used with the semiconductor cadmium telluride to fabricate solar cells given its optimal band gap energy $(2.42 \mathrm{eV})$ for optical windows [1]. Chemical bath deposition (CBD) is an experimented and widely used technique in the industry and in the research area for CdS thin films deposition by the fast, simple and low-cost method [2]. The composition of the chemical bath and the kinetics of deposition have been reported in the literature $[3,4]$ such that now very known functional recipes are normally used for CdS films preparation depending on the chemical compounds selected for the $\mathrm{Cd}$ and $\mathrm{S}$ ions production. In the traditional recipe, a cadmium salt is dissolved in a basic ammonium solution, stirred and heated during thiourea addition, which starts the film deposition on indium thin oxide (ITO) surfaces over glass. Several efforts have been made in this way changing the temperature, concentration of chemical components, $\mathrm{pH}$, and rate and type of bath agitation. Although the kinetics of deposition has been reported, studies of the physical properties achieved on the CdS films as a function of the chemical bath concentration are scarce in the literature. An important requirement of the $\mathrm{CdS}$ films for solar cells applications is the smooth surface and the minor quantity of hillocks produced on the surface after preparation, added to the optimal thickness for better functionality. In this work, an analytical study of the predominant cadmium species depending on $\mathrm{NH}_{3}$ and $\mathrm{OH}^{-}$concentrations give optimal conditions of the chemical composition to achieve different qualities on the deposited films.

\section{THEORY}

It is well known the influence of $\mathrm{pH}$ and $\mathrm{NH}_{3}$ in the stability of different $\mathrm{Cd}^{2+}$ species in solution. The cadmium (II) ions form a variety of complexes with ammonium and hydroxide, according with the following equation:

$$
\mathrm{Cd}^{2+}+\mathrm{n} \mathrm{L}=\mathrm{CdL}_{n}^{2+} \quad \beta_{n, L}=\left[\mathrm{CdL}_{n}^{2+}\right] /\left[\mathrm{Cd}^{2+}\right][\mathrm{L}]^{n}(1)
$$

being $\beta_{n, L}$ the stability constant of the corresponding reaction. The complexes can be formed with the hydroxide ion $(\mathrm{L}=$ $\mathrm{OH}^{-}, \mathrm{n}=1$ to 4$)$, the ammonium ( $\mathrm{L}=\mathrm{NH}_{3}, \mathrm{n}=1$ to 6$)$, and even with thiourea $\left(\mathrm{L}=\mathrm{SC}\left(\mathrm{NH}_{2}\right)_{2}, \mathrm{n}=1\right.$ to 4$)$, although these last complexes are less stable and normally they are not considered to interfere in the mechanism of reaction and deposition of the film [3]. According with this mechanism, the complex $\mathrm{Cd}\left(\mathrm{NH}_{3}\right)_{4}^{2+}$ is adsorbed in the surface as $\mathrm{Cd}(\mathrm{OH})_{2}$ before reacting with thiourea to form the CdS film. If the kinetics of deposition is modified, it is possible to change the physical properties of the CdS films. A reasonably way to drive these variations is through $\mathrm{pH}$ and $\mathrm{pNH}_{3}$ changes to test the relative cadmium species in solution, according with the stability constants. This can be easily visualized using predominance zone diagrams, which have been tested to be useful in analytical chemistry [5]. According with this method of generalized species and equilibrium, the stability constants reported at room temperature [3] were used to detect the chemical zone in which $\mathrm{Cd}\left(\mathrm{NH}_{3}\right)_{4}^{2+}$ predominates as an approximation to the conditions at the temperature of deposition. More details to obtain this diagram are found elsewhere [6]. Thus, Fig. 1 is the diagram obtained for $\mathrm{Cd}(\mathrm{II})$ species in solution as a function of $\mathrm{pH}$ and $\mathrm{pNH}_{3}$, showing the surface where the complex $\mathrm{Cd}\left(\mathrm{NH}_{3}\right)_{4}^{2+}$ is present in concentrations over $50 \%$ of the total $\mathrm{Cd}(\mathrm{II})$ in solution. The lines define the specific zones at which the $\mathrm{Cd}\left(\mathrm{NH}_{3}\right)_{4}^{2+}$ is present for half the concentration of the cadmium species. The surfaces around this zone are those related to other predominant species of cadmium in solution: the area $\alpha$ is for $\mathrm{Cd}\left(\mathrm{NH}_{3}\right)_{5}^{2+}$, the area $\beta$ is for $\mathrm{Cd}\left(\mathrm{NH}_{3}\right)_{3}^{2+}$, the area $\gamma$ is for $\mathrm{Cd}(\mathrm{OH})_{3}^{-}$and the area $\delta$ is for $\mathrm{Cd}(\mathrm{OH})_{4}^{2-}$.

The border lines are derived from the stability constants and change with temperature; however, the diagram may be useful 


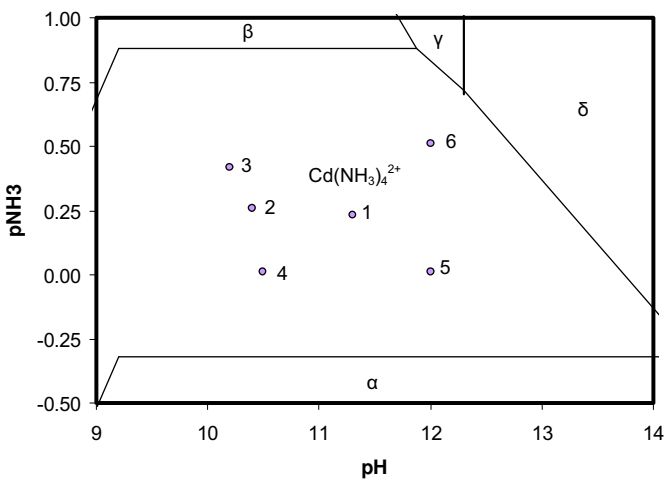

FIG. 1: $\mathrm{Cd}(\mathrm{II})$ predominance zone diagram as a function of $\mathrm{pH}$ and $\mathrm{pNH}_{3}$ at room temperature. See the text for details.

for the analysis of the influence of $\mathrm{pH}$ and $\mathrm{pNH}_{3}$ on the quality of deposited films. In this work, a variation of the $\mathrm{pH}$ and $\mathrm{pNH}_{3}$ initial conditions is tested in order to understand the physical properties of the CdS films deposited by CBD. The numbered points in the Fig. 1 represent the six experimental conditions used to deposit CdS films into the optimal zone for a fixed quantity of cadmium and thiourea.

\section{EXPERIMENTAL}

CdS films were prepared under different chemical bath conditions around the determined optimal zone (i.e. different $\mathrm{pH}$ values and ammonium concentrations). Every chemical bath was obtained mixing four individual solutions: $20 \mathrm{ml}$ of 0.02 $\mathrm{M}$ cadmium chloride, $20 \mathrm{ml}$ of ammonium nitrate (3.3, 3.1, $2.2,5.5,5.5$ and $1.8 \mathrm{M}$, respectively), $50 \mathrm{ml}$ of potassium hydroxide $(1.3,1.2,0.8,2.1,2.1$ and $0.7 \mathrm{M}$, respectively) and 20 $\mathrm{ml}$ of $0.2 \mathrm{M}$ thiourea. The initial chemical concentrations in the deposition bath after mixing the individual solutions are given in Table I. As seen, cadmium chloride and thiourea concentrations were not varied between experiments. The $\mathrm{pH}$ was determined with a digital $\mathrm{pH}$-meter and the $\mathrm{pNH}_{3}$ was approximately calculated. During deposition, magnetic agitation and bath temperature, $\mathrm{T}=348 \pm 2 \mathrm{~K}$, were kept constant.

TABLE I: Initial concentrations of the chemical bath for the six experiments performed in this work. The values for $\mathrm{pH}$ were measured and those for the $\mathrm{pNH}_{3}$ were calculated.

\begin{tabular}{|l|l|l|l|l|l|l|}
\hline Exp & $\begin{array}{l}\mathrm{CdCl}_{2} \\
(\mathrm{mM})\end{array}$ & $\begin{array}{l}\mathrm{NH}_{4} \mathrm{NO}_{3} \\
(\mathrm{M})\end{array}$ & $\begin{array}{l}\mathrm{KOH} \\
(\mathrm{M})\end{array}$ & $\begin{array}{l}\mathrm{CS}\left(\mathrm{NH}_{2}\right)_{2} \\
(\mathrm{mM})\end{array}$ & $\mathrm{pH}$ & $\mathrm{pNH}_{3}$ \\
\hline 1 & 3.64 & 0.607 & 0.591 & 36.4 & 11.3 & 0.23 \\
\hline 2 & 3.64 & 0.562 & 0.559 & 36.4 & 10.4 & 0.26 \\
\hline 3 & 3.64 & 0.396 & 0.357 & 36.4 & 10.2 & 0.42 \\
\hline 4 & 3.64 & 1.000 & 0.946 & 36.4 & 10.5 & 0.01 \\
\hline 5 & 3.64 & 1.000 & 0.975 & 36.4 & 12.0 & 0.01 \\
\hline 6 & 3.64 & 0.324 & 0.316 & 36.4 & 12.0 & 0.51 \\
\hline
\end{tabular}

CdS films were deposited on ITO/glass substrates from
Delta Technologies $\left(\mathrm{R}_{s}=10 \pm 2 \Omega, 200 \mathrm{~nm}\right.$ thick and 2.53 x $10^{-6} \Omega \cdot \mathrm{m}$ as electrical resistivity). Before deposition, ITO substrates were cleaned with soap, trichloroethylene, acetone and isopropyl alcohol, rinsing with distilled water between each stage, according with a standard method. For each experiment, five ITO substrates are immersed into the chemical bath with cadmium chloride, ammonium nitrate and potassium hydroxide. Then the bath is heated at $348 \mathrm{~K}$, the deposition temperature. The chemical bath was heated and stirred with a heater-stirrer plate and its temperature was measured with a $\mathrm{Hg}$-thermometer located into the chemical bath. After the deposition temperature is reached, the thiourea is added and the CdS formation starts. Each ITO substrate was removed from the chemical bath one by one after 10, 20, 30, 40 and $50 \mathrm{~min}$, and immediately rinsed with distilled water into an ultrasonic cleaner. Pale-yellow CdS films were obtained on both substrate faces and the glass surface is cleaned with a $10 \% \mathrm{HCl}$ solution to eliminate the CdS film from this face.

The surface morphology of the dried films was imaged with the atomic force microscopy (AFM) technique (CP Autoprobe). The band gap energy was computed from spectral data obtained with a StellarNet EPP2000 spectrophotometer in the ultraviolet-visible range (from 200 to $850 \mathrm{~nm}$ of wavelength) using a special adaptation made in our laboratory for analysis of solid samples. The ITO spectrum is used as a reference to eliminate its effect in the band gap of the CdS film. The thickness of CdS films was measured by using a Dektak 8 profile-meter after forming a step in the film-corner with the $\mathrm{HCl}$ solution.

\section{RESULTS}

Figure 2 shows the film thickness obtained and the corresponding band gap energy as a function of deposition time for the experiments 1,2,3 and 5.

Experiment 4 had an extremely slow deposition and experiment 6 did not have any deposition. It is possible to observe (Fig. 2a) that the rate of deposition for the experiment 1 is the fastest at the beginning but becomes slower very soon. On the other hand, the experiment 2 shows a slow deposition during the first part, followed by a good rate deposition which gives the thickest film between all the tests. Experiments 3 and 5 showed slow rates of deposition during all the first $50 \mathrm{~min}$ of the CBD. Also Fig. 2b allows seeing the kinetic differences between both experiments using the computed band gap energy. Experiments 2 and 3 show larger values of the band gap energy for the first films (10-20 $\mathrm{min})$ due to the small measured thickness related with the confinement effect. After that, band gap values are similar to the typical results near $2.4 \mathrm{eV}$. The differences among experiments 1 and 2 allow conclude that it is possible to change not only the rate of deposition but also the film quality through a change of $\mathrm{pH}$ in the bath. More precise differences could be seen when bigger changes were made in the chemical composition, as shown in Table II.

Experiments 2, 3 and 4 give how important is the ammonium concentration at similar values of $\mathrm{pH}$. Of these three experiments, the number 3 has the lowest ammonium concen- 

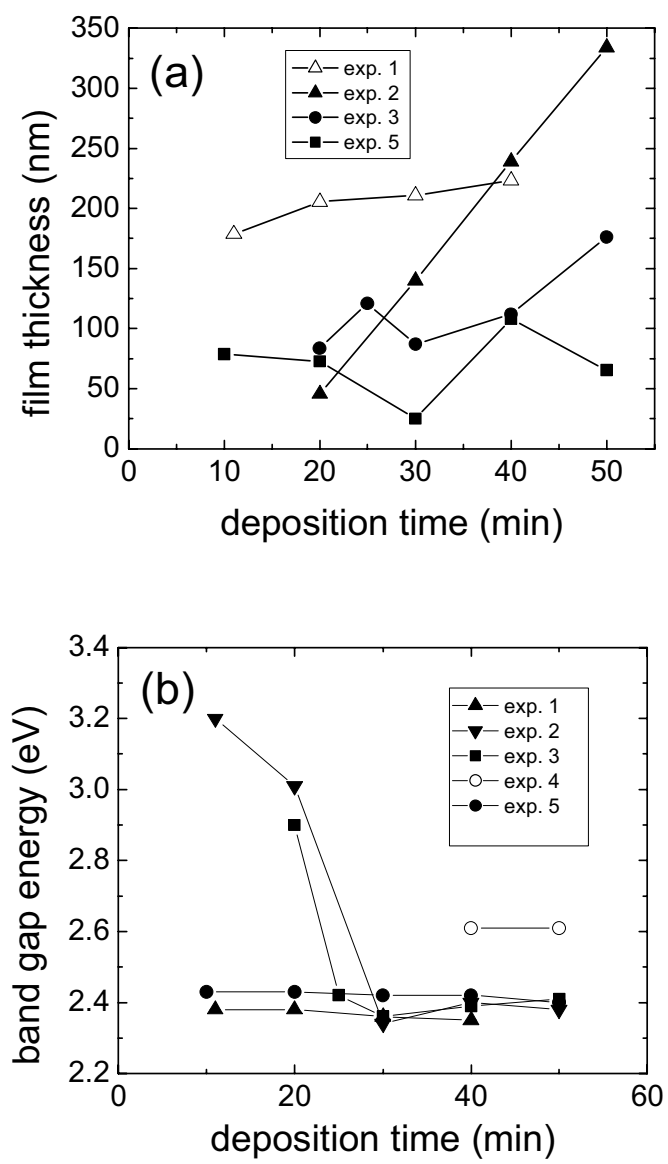

FIG. 2: a) CdS film thickness vs. deposition time for the different experiments; b) band gap energy vs deposition time for different experiments. Experiments 4 and 6 did not have enough CdS deposition during the first $50 \mathrm{~min}$.

tration and follows a slower kinetics of deposition than experiment 2: the thickness after 50 min was smaller for the film in experiment 3 when compared with experiment 2, but the band gap energy reaches similar values. Experiment 4, on the other hand, has a bigger ammonium concentration and had the slowest kinetics of deposition. The final thickness is significantly lower and a similar value of band gap energy was reached only after $90 \mathrm{~min}$ of deposition.

Experiments 5 and 6 give interesting results for more basic values of $\mathrm{pH}$. When a high ammonium concentration was used in experiment 5, an inhibition of the deposition was found since the first minutes, just after a thin film was deposited with an unchanged morphology and similar band gap. However, for experiment 6 , in which a low ammonium concentration was used, the deposition of the film was totally inhibited. It is important to say that in these two experiments the color of the solution changed to yellow immediately after the addition of thiourea, although the deposition was inhibited since the first minutes of reaction.

Some typical surface morphology images of CdS films after 20 min of deposition are shown in Fig. 3 as obtained by the AFM technique. These images were taken for the six experi-
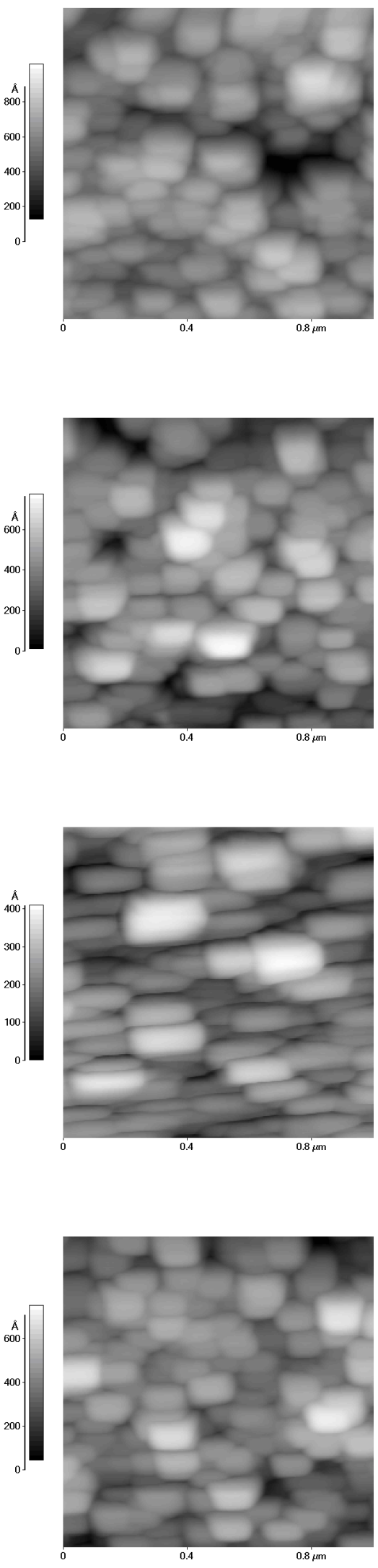

FIG. 3: Typical $\left(1 \mathrm{x} 1 \mu \mathrm{m}^{2}\right)$ AFM images of CdS film surface after 20 min of deposition for experiments: (a) 1, (b) 2, (c) 3 and (d) 5 . Corresponding maximum z-scale is: a) $80 \mathrm{~nm}$, b) $60 \mathrm{~nm}$, c) $40 \mathrm{~nm}$, and d) $60 \mathrm{~nm}$. 
TABLE II: The film thickness and band gap energy values determined at the end of each experiment.

\begin{tabular}{|l|l|l|}
\hline Exp. & $\begin{array}{l}\text { Thickness }(\mathrm{nm}) \text { at } \mathrm{t}= \\
50 \mathrm{~min}\end{array}$ & $\begin{array}{l}\text { Band gap energy }(\mathrm{eV}) \text { at } \mathrm{t} \\
=50 \mathrm{~min}\end{array}$ \\
\hline $1^{a}$ & 223 & 2.35 \\
\hline 2 & 334 & 2.38 \\
\hline 3 & 176 & 2.41 \\
\hline 4 & Not determined & $2.43^{b}$ \\
\hline 5 & 65 & 2.43 \\
\hline 6 & No deposition & No deposition \\
\hline
\end{tabular}

${ }^{a}$ The film at $50 \mathrm{~min}$ was not analyzed. Results for $\mathrm{t}=40 \mathrm{~min}$ are presented indeed.

${ }^{b}$ This value is for the film deposited after $\mathrm{t}=90 \mathrm{~min}$.

ments every ten minutes. Images for the experiments 4 and 6 did not show any significant deposition.

It is possible to observe that for slight variations in the $\mathrm{pH}$ and the $\mathrm{pNH}_{3}$ values of the chemical bath, the kinetics of deposition and the corresponding quality of the CdS films can be driven in accordance with the necessities of the material applications. Around area $\alpha$ in Fig. 1, in which high concentrations of ammonium are present, there is a zone with very slow deposition rates, indicating that $\mathrm{Cd}\left(\mathrm{NH}_{3}\right)_{5}^{2+}$ have a negative influence in the mechanism of reaction. Near area $\beta$, although rates deposition also diminish, a major control is allowed to define slight variations in the film properties; in this zone, the conversion of $\mathrm{Cd}\left(\mathrm{NH}_{3}\right)_{3}^{2+}$ to $\mathrm{Cd}\left(\mathrm{NH}_{3}\right)_{4}^{2+}$ is not a problematic step for the total process. Finally, near the areas $\gamma$ and $\delta$, the formation of cadmium hydroxides gives a dramatic example in which the deposition of CdS films is totally inhibited.

\section{CONCLUSION}

Large differences were found in the measured characteristics of the films between each chemical bath condition such that the $\mathrm{pH}$ and $\mathrm{pNH}_{3}$ of the solution play a key role. Different rate depositions, i.e. different film qualities, can be achieved with minor changes in the chemical concentration of the solution. These results can be interesting for the optical window design of the CdTe/CdS/ITO solar cells given the possibility to control the thickness and rate deposition of the CdS films deposited. Accordingly with the results, there is a compromise between ammonium concentrations and $\mathrm{pH}$ values for an adequate $\mathrm{CdS}$ film deposition. It is recommended to avoid: (i) more basic values of $\mathrm{pH}$ when ammonium concentration is low, or (ii) high ammonium concentrations with lower values of $\mathrm{pH}$. Low ammonium concentrations are possible with less basic solutions and high ammonium concentrations are allowed with bigger $\mathrm{pH}$ values. Intermediate values of $\mathrm{pH}$ (around 11) and ammonium concentration (around $0.2 \mathrm{M}$ ) give fast depositions. Nevertheless, slower rates are recommended in order to improve the quality of the films. Further experiments are planned to analyze more in detail these effects on CdS applications, exploring specially the zone around $\mathrm{pH}=10$ and $\mathrm{pNH}_{3}=0.4 \mathrm{M}$.

\section{Acknowledgement}

This work was supported by Conacyt (México) through project 38480-E. Authors thank to Oscar Ceh and Emilio Corona for their technical help.
[1] Y. J. Chang, C. L. Munsee, G. S. Herman, J. F. Wager, P. Mugdur, D. H. Lee, and C. H. Chang, Surf. Interface Anal. 37, 398 (2005).

[2] A. Arias-Carbajal Reádigos, V. M. García, O. Gomezdaza, J. Campos, M. T. S. Nair, and P. K. Nair, Semicond. Sci. Technol. 15, 1022 (2000).

[3] R. Ortega-Borges, D. Lincot, J. Electrochem. Soc. 140, 3464 (1993).
[4] J. M. Doña, J. Herrero, J. Electrochem. Soc. 144, 4081 (1997).

[5] M. E. Páez-Hernández, M. T. Ramírez, A. Rojas-Hernández, Talanta 51, 107 (2000).

[6] A. Maldonado, R. Asomoza, J. Canetas-Ortega, E. P. Zironi, R. Hernández, R. Patiño, and O. Solorza-Feria, Solar Energy Materials \& Solar Cells 57, 331 (1999). 